\title{
Implementation of Digital Literacy in Elementary Schools
}

\author{
Nufaisah Masyhura1*, Zaka Hadikusuma Ramadan²
}

1,2 Pendidikan Guru Sekolah Dasar, Universitas Islam Riau, Riau, Indonesia

\section{ART I CLE IN F O}

Article history:

Received Mei 22, 2021

Revised Mei 29, 2021

Accepted Agustus 14, 2021

Available online November 25, 2021

\section{Kata Kunci:}

Literasi Digital, Sekolah Dasar,

Pembelajaran Jarak Jauh

Keywords:

Digital Literacy, Primary School, Distance Learning

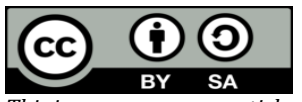

This is an open access article under the $\mathrm{CC}$ BY-SA license.

Copyright (C) 2021 by Author. Published by Universitas Pendidikan Ganesha.

\begin{abstract}
A B S T R A K
Literasi digital adalah salah satu bentuk perkembangan era revolusi 4.0 dimana kita bisa mengakses berbagai informasi yang diinginkan secara cepat. Tentunya dilingkungan sekolah literasi digital sangat memberikan dampak terutama pada proses pembelajaran. Tujuan dari penelitian ini adalah untuk menganalisis bagaimana implementasi literasi digital disekolah dasar. Jenis penelitian ini adalah kualitatif dengan desain penelitian yang dilakukan dengan 4 tahap: pertama, fokus penelitian. Kedua, pelaksanaan penelitian (Observasi, Wawancara). Ketiga, analisis data. Keempat, hasil penelitian, subjek penelitian yaitu, 1 orang kepala sekolah, 6 orang guru dan 6 orang siswa. Teknik pengumpulan data dan instrumen penelitian meliputi lembar observasi dan pedoman wawancara. Analisis data menggunakan analisis interaktif model dari Miles dan Huberman. Hasil penelitian menunjukkan penerapan literasi digital di sekolah dasar masih kurang maksimal. Hal ini dibuktikan ketika melakukan wawancara dan observasi bahwa proses pembelajaran masih berpusat kepada guru dan umumnya menggunakan media literasi digital whats app group. Selain itu, gebrakan tentang literasi digital dilingkungan sekolah masih kurang sehingga implementasi literasi digital hanya sebatas pemahaman saja. Hambatan yang dialami seperti siswa kesulitan memahami materi dan kuota internet yang terbatas. Oleh karena itu, untuk memaksimalkan imlementasi literasi digital di sekolah dasar perlu program seperti mengadakan pelatihan, buku pedoman dan sarana prasarana literasi digital.
\end{abstract}

\section{A B S T R A C T}

Digital literacy is one form of development in the 4.0 revolution era where we can access various desired information quickly. Of course, the digital literacy school environment impacts the learning process significantly. This study aims to analyze how the implementation of digital literacy in elementary schools. This type of research is qualitative with a research design in 4 stages: first, research focus. Second, research implementation (Observation, Interview). Third, data analysis. Fourth, the study results, the research subjects were 1 principal, 6 teachers and 6 students. Data collection techniques and research instruments include observation sheets and interview guidelines-data analysis using an interactive analysis model from Miles and Huberman. The study results show that the application of digital literacy in elementary schools is still not optimal. It is proven when conducting interviews and observations that the learning process is still teacher-centred and generally uses what app group digital literacy media is. In addition, the breakthrough about digital literacy in the school environment is still lacking, so that the implementation of digital literacy is only limited to understanding. Barriers experienced include students having difficulty understanding the material and limited internet quota. Therefore, to maximize the implementation of digital literacy in elementary schools, programs such as conducting training, manuals and digital literacy infrastructure are needed.

\section{INTRODUCTION}

Currently, distance learning is applied during the pandemic. There are several determinants of distance learning success, including teachers, learners, and technology (Basar, 2021; Monitorir, 2020; Simanjuntak et al., 2020). Technology can support the implementation of digital literacy in schools (Hanik, 2020; Sari, 2019). However, the online learning process harms students, especially those who cannot use supporting facilities during online learning (Arizona et al., 2020; Hutauruk \& Sidabutar, 2020; Windhiyana, 2020). The 21st century, known as the information and technology era, brings new changes in the order of human life (Benbow et al., 2021; Chai \& Kong, 2017; Gürsoy, 2021) Information sources occur so quickly that the distance limits are getting narrower because they are connected by technology and information. The 2013 curriculum was formed as a school literacy movement that places students as subjects in learning, not objects (Aiman et al., 2020; Suyono et al., 2017). The teacher acts as a facilitator, not an object.

So, with this digital era, digital literacy is very much needed in helping the learning process and school services run (Hanik, 2020; Putri, 2020). Various studies related to digital literacy discussed increasing and measuring digital literacy during the pandemic, which discussed that there was an increase in digital literacy (Rochadiani et al., 2020; Irhandayaningsih, 2020). Based on other research results, students who are good at utilizing digital literacy benefit from having more sources of information and tend 
to have exemplary achievements in the learning process (Rastati, 2018; Santoso \& Lestari, 2019). It is supported because digital literacy plays a vital role as a form of independent learning (Banyu Biru et al., 2020; Kurnia \& Astuti, 2017a). So that students can access various quality learning resources not only at school but also outside of school independently (Irhandayaningsih, 2020; Nahdi \& Jatisunda, 2020). The 21st-century learning model, namely, learning, is no longer centred on the teacher but through the students independently (Hanik, 2020).

However, based on the initial interviews that the researchers conducted with homeroom teachers, it was found that the implementation of digital literacy during online learning was still not optimal. Among the contributing factors is a lack of understanding and unfamiliarity with digital literacy. However, in utilizing electronic media such as accessing various games and social media, students generally have shrewdness in using it. The existence of electronic media certainly makes implementing digital literacy easier. It is just that the overall understanding and knowledge of digital literacy is not evenly distributed. It is also in line with the results of previous research, which explained that there are still many schools that do not contribute to the application of digital literacy. Data evidence that universities (56.4\%) are the primary users of digital literacy, followed by the government (14.34\%). ), then non-governmental organizations (5.32\%), schools and corporations respectively (3.68\%), professional associations and mass organizations (2.86\%), then the media (0.4\%), and others (2.86\%) (Desi, 2020; Kurnia \& Astuti, 2017). Of course, breakthroughs and actions are needed to implement digital literacy in schools to achieve digital literacy-based learning activities. It can be done by conducting teacher training, teacher and student manuals and directives. The results of previous research on increasing digital literacy during the COVID-19 pandemic provide digital content and online seminars conducted in the community (Rochadiani et al., 2020).

Digital literacy plays an essential role in acquiring knowledge with a broader scope. Digital literacy can help children learn (Kurnia \& Astuti, 2017a; Masitoh, 2018; Safitri et al., 2020). In addition, it makes it easier for teachers and students to conduct distance learning during the pandemic. Digital literacy can be defined as a competency to know and understand and use information that can be accessed through digital technology (Anggrasari, 2020; Sahidillah \& Miftahurrisqi, 2019). Students can access, manage, analyze and develop and build new knowledge by communicating with new people to be involved in the community (Fatimah, 2020; Asari et al., 2019). So, it can be said that digital literacy can make it easier for students and teachers to be able to use, create information, and information through digital media intelligently and intelligently during the learning process and activities at school (Huseyin et al., 2015; Purnama et al., 2021; Rizaldi et al., 2020). Indeed, during the pandemic, the use of information and communication technology (I.C.T.) in online learning is an innovation in education (Ghory \& Ghafory, 2021; Maulana \& Padang, 2021; Teräs et al., 2020). This technology is a trigger for the emergence of digital literacy to increase reading interest in Indonesian children (Balan et al., 2019; I. I. M. Putri et al., 2020). In addition, digital literacy is also needed by individuals to know the development of the world and make individuals wiser in understanding all the problems found (Balan et al., 2019; Safitri et al., 2020). Reading literacy also influences student achievement (Koyuncu \& Firat, 2020). The digital era can also be used in schools by borrowing digital-based books (Kurnianingsih et al., 2017). However, there are still a few schools that implement this program.

The implementation of digital literacy has an influence on teachers to look for information technology (IT)-based teaching patterns so that teachers can search for information and learning resources not only in libraries but also through the use of technology (Pohan \& Suparman, 2020; Sujendra Diputra et al., 2020; Tse et al., 2019). Apart from teachers, parents also guide children in using digital media carefully (Garbacz et al., 2015; Nur Ika Fatmawati, 2019). Digital literacy plays a crucial role in the formation of students' character. Therefore, it is necessary to assist not only teachers but also to involve parents. For this reason, a strategy for implementing digital literacy in schools is needed, which includes, first, strengthening the provision of facilitators; several ways to develop digital literacy, training and assistance for e-resource search strategies are explained-technology-based media preparation training. Second, increasing the level and variety of quality learning resources; More digital literacy reading materials in the library; Provision of educational sites as a source of learning for school residents; The use of educational applications during online learning as a source of learning for school residents; Carry out activities to make school bulletins and class bulletins. Third, expanding access to quality learning resources and the scope of learning participants; Provision of computers and internet access in schools; Provision of information through digital media (Hanik, 2020; Purnama et al., 2021; Rizaldi et al., 2020).So, the teacher as a facilitator in developing student knowledge is assisted by using digital literacy, which will include broader knowledge tailored to students' characteristics to generate student interest in learning (Awe \& Benge, 2017; Febriliani, 2018; Radyuli \& Rahmat, 2017). If children's interest in learning increases, learning outcomes will also increase. 
Digital literacy can be implied in several forms, such as using google apps, using what's app as a digital literacy media and then digital literacy through social media youtube (Khosiyah \& Gunawan, 2019; Sahidillah \& Miftahurrisqi, 2019; Salehudin, 2020). In this case, it is necessary to supervise teachers and parents because children tend to develop skills and competencies through technology without any prior discussion (Marsh, 2016; Pramudyani, 2020). Besides that, the role of parents in assisting and guiding and directing students to study at home is quite effective in overcoming student learning difficulties (Akhyar et al., 2021; S. W. Anggraeni et al., 2021). Parents feel some of the obstacles are time problems, the ability to use technology, and the lack of ability to be a teacher while at home (Lase et al., 2021). Therefore, understanding technology and understanding the role of being a teacher for children at home is necessary to support online learning activities.

This study will describe the implementation of digital literacy specifically in elementary schools so that the implementation process can be considered before implementing digital literacy. Therefore, it is necessary to research so that all obstacles and problems in the implementation of digital literacy can be known. Based on the problems above, this study aims to analyze how implementing digital literacy in elementary schools during online learning, be it for teachers or students and education staff. So, research was conducted to review how to implement digital literacy in elementary schools.

\section{METHOD}

This type of research is qualitative with research procedures carried out in 4 stages: (1) Research focus, research focuses on class references and class culture references, (2) Research implementation, at SDN 21 Pekanbaru which includes (Observation, Interview) the principal, teachers, students (3) data analysis using the Miles and Huberman model, (4) research results, in the form of a collection of data in the form of field facts that researchers conclude based on the research conducted. Furthermore, the research subject, namely, 1 principal, 6 teachers and 6 students, then data collection techniques and research instruments include observation sheets and interview guidelines. Research indicators and sub-indicators are presented in Table 1.

Table 1. Research indicators and sub-indicators

\begin{tabular}{|c|c|c|c|}
\hline Indicator & Sub Indicator & Interview & Observation \\
\hline \multirow[t]{3}{*}{$\begin{array}{l}\text { class } \\
\text { reference }\end{array}$} & $\begin{array}{l}\text { Total digital literacy training attended by principals, teachers, } \\
\text { and education staff. }\end{array}$ & $\sqrt{ }$ & - \\
\hline & $\begin{array}{l}\text { The intensity of the application and use of digital literacy in } \\
\text { learning activities. }\end{array}$ & $\sqrt{ }$ & $\sqrt{ }$ \\
\hline & $\begin{array}{l}\text { The level of understanding of principals, teachers, education } \\
\text { staff, and students in using digital media and the internet. }\end{array}$ & $\sqrt{ }$ & $\sqrt{ }$ \\
\hline \multirow{6}{*}{$\begin{array}{l}\text { Reference } \\
\text { school } \\
\text { culture }\end{array}$} & $\begin{array}{l}\text { Number and variety of digital-based reading materials and } \\
\text { teaching aids. }\end{array}$ & $\sqrt{ }$ & - \\
\hline & Procedure for borrowing digital themed books. & $\sqrt{ }$ & - \\
\hline & $\begin{array}{l}\text { Number of activities in schools that utilize technology and } \\
\text { information }\end{array}$ & $\sqrt{ }$ & $\sqrt{ }$ \\
\hline & $\begin{array}{l}\text { Number of presentations of school information using digital } \\
\text { media or web sites }\end{array}$ & $\sqrt{ }$ & $\sqrt{ }$ \\
\hline & $\begin{array}{l}\text { Number of school policies regarding the use and utilization of } \\
\text { information and communication technology in the school } \\
\text { environment. }\end{array}$ & $\sqrt{ }$ & - \\
\hline & $\begin{array}{l}\text { Level of utilization and application of information and } \\
\text { communication technology in terms of school services }\end{array}$ & $\sqrt{ }$ & - \\
\hline
\end{tabular}
Kementrian Pendidikan dan Kebudayaan (Ginanjar et al., 2019)

Analysis of the data used in this study is the model of Miles and Huberman. The sections in the first data analysis, data collection, were obtained through observations and interviews conducted on principals, teachers and students. Second; Data reduction, analyzing the data that has been collected, then processed and verified. Third; Presentation of data, compiling the information obtained in more detail to be presented. Fourth, drawing conclusions and verification, the final stage of data processing contains a conclusion based on data patterns arranged systematically. The technique used to analyze the data is descriptive qualitative and quantitative analysis. 


\section{RESULT AND DISCUSSION}

\section{Result}

Based on the researchers' observations, the first finding was that the understanding of principals and teachers on technology was sound. It was seen when using technology in the form of laptops and cellphones-in the second finding, observing the application of technology into digital literacy is still lacking, especially in the learning process. It is evidenced when the learning process takes place. The use of digital literacy generally only uses what app group media is. Based on the interviews, it was found that teachers and students had difficulties using google apps. It is evidenced by the teacher only using the what's app group as a digital literacy media during the learning process, where the teacher distributes material and youtube links as additional material. Based on the research results above, elementary school students generally use digital media in the form of WhatsApp, and one class uses google apps in the form of google classroom, where the teacher provides material and then conducts discussions. However, it did not run optimally because it was constrained in making e-mails, so the learning process returned to using WhatsApp.

The implementation of digital literacy is essential for the learning process, especially during online learning caused by the coronavirus disease (Covid-19), which causes all activities to be carried out virtually. Thus the implementation of digital literacy has a significant influence on the running of the online learning process. With the implementation of digital literacy, it is expected that students can do independent learning so that learning is not only teacher-centred. Students can find a problem then students determine the answer to the problem based on discussion with the teacher. The role of the teacher can be helped by implementing the implementation of digital literacy in the learning process. Reciprocal interactions between teachers and students also need to be considered to create productive learning. Based on the research conducted, the results are presented in Table 2.

Table 2. Source of research data processing

\begin{tabular}{|c|c|c|c|}
\hline Indicator & Sub indicator & Observation & Interview \\
\hline $\begin{array}{l}\text { class } \\
\text { reference }\end{array}$ & $\begin{array}{l}\text { Total digital literacy } \\
\text { training attended by } \\
\text { principals, teachers, } \\
\text { and education staff. } \\
\text { The intensity of the } \\
\text { application and use } \\
\text { of digital literacy in } \\
\text { learning activities. }\end{array}$ & $\begin{array}{l}\text { It went smoothly, it was just } \\
\text { that there were some } \\
\text { obstacles, such as the use of } \\
\text { digital literacy through } \\
\text { google apps, students were } \\
\text { constrained in making } \\
\text { emails, then in the learning } \\
\text { process using whats app }\end{array}$ & $\begin{array}{l}\text { The total digital literacy training } \\
\text { attended by principals, teachers, } \\
\text { and education personnel was } \\
\text { approximately } 3 \text { times. } \\
\text { The implementation is still not } \\
\text { optimal in its implementation, } \\
\text { especially in interactions during } \\
\text { the subsequent learning process } \\
\text { due to network limitations and } \\
\text { quotas, but using digital literacy is } \\
\text { very helpful in learning activities. }\end{array}$ \\
\hline
\end{tabular}

The level of The principal has an understanding of understanding of using principals, teachers, digital media and the education staff, and internet. Teachers and students in using digital media and the internet.

$\begin{array}{ll}\text { Class } & \text { Number and variety } \\ \text { culture } & \text { of digital-based } \\ \text { reference } & \text { reading materials } \\ & \text { and teaching aids. } \\ & \text { Procedure for } \\ & \text { borrowing digital } \\ & \text { themed books. }\end{array}$
students have an understanding of using whats app digital media during the learning process, on google apps only a few students use it. -
The principal has an understanding of using digital media and the internet. While teachers and students are proficient in the learning process using whats app groups and youtube, it's just that they are still lacking in using the google app. This is done using electronic media such as cellphones and laptops.

There are no digital-based reading materials and teaching aids

Book lending is done manually. Students borrow textbooks through the homeroom teacher, 


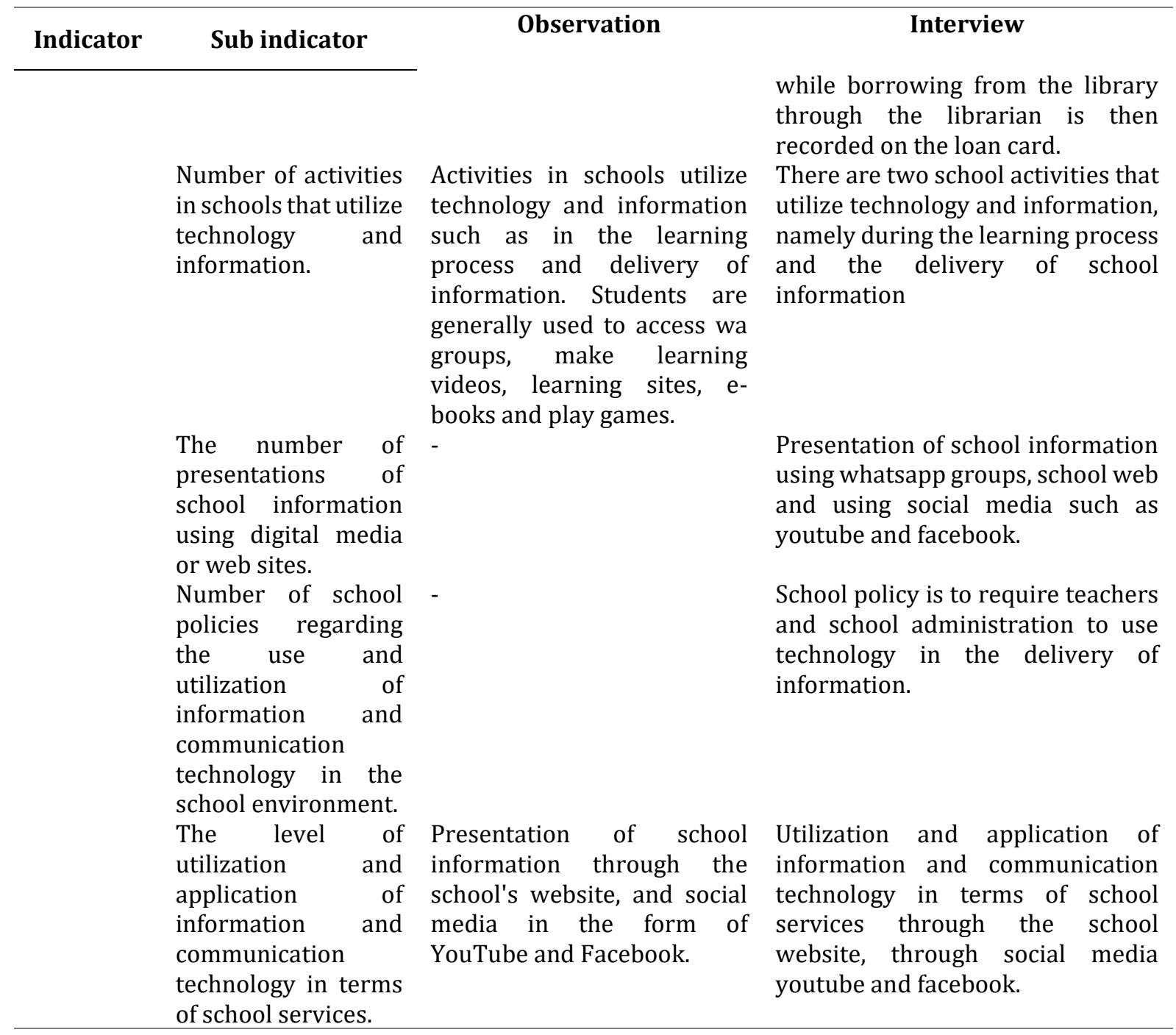

Based on observations, the comprehensive digital literacy training attended by principals, teachers, and education staff was carried out approximately three times. Digital literacy training has an essential role as a supporting aspect for educators. In the aspect of the procedure for borrowing digital-themed books, it has not been carried out because, in schools, the procedure for borrowing digital-themed books is still done manually, where students borrow textbooks through the homeroom while borrowing in the library through the library manager is then written on the loan card. There are two aspects of the number of school activities that utilize technology and information, namely, during the learning process and school information services. Students generally use information and communication technology to access WhatsApp groups, make learning videos, learning sites, electronic books, and play games in learning activities. Meanwhile, teachers use the school's web and school social media for the delivery of information. Based on observations on aspects of the level of utilization and application of information and communication technology in school services. It is good because schools apply information and communication technology in terms of school services, such as presenting school information through the school's web and social media in the form of YouTube and Facebook, making it easier for students to obtain information about the school. The amount of presentation of school information using digital media or websites is presented on the school website and school social media. However, the class teacher conveys it via WhatsApp group if it is specific. In the number of school policies regarding the use and utilization of information and communication technology in the school environment, there are 2, namely the learning process that uses information and communication technology and school services that utilize information and communication technology to facilitate all activities that can be accessed anywhere and anytime. At the level of utilization and application of information and communication technology in terms of school services, it is good because it has been based on communication and information technology in a school website and school social media such as YouTube and Facebook. Then there are electronic devices as support, namely the availability of computer equipment. So, based on the results of observational data and interviews conducted, it was concluded that 
digital literacy training dramatically influences the implementation of digital literacy in schools. With the training, the level of the teacher's ability in managing learning activities will increase.

\section{Discussion}

Openness about deficiencies during the process of implementing digital literacy is also needed to evaluate and review any problems and obstacles during the online learning process. Electronic media and digital media to support digital literacy are good (Kurnia \& Astuti, 2017a; Lacka et al., 2021; Ristanto et al., 2020). Of course, the ability to use electronic media is beneficial in applying digital literacy because electronic media supports the implementation of digital literacy (Agustini et al., 2020; Masitoh, 2018). Weaknesses such as the limitations of students in accessing digital literacy are also a note for teachers to provide an understanding of utilizing digital literacy in the learning process. This deficiency can be minimized with further guidance to students (Fatimah, 2020; Sahidillah \& Miftahurrisqi, 2019). The application of digital literacy in the learning process, of course, must have preparation before its implementation, such as completing facilities and targets that support digital literacy, e-learning-based literacy and holding digital literacy-based training (Agustini et al., 2020; Kurnianingsih et al., 2017). Based on the above statement, there are obstacles to implementing digital literacy at SDN 21 Pekanbaru using the WhatsApp group media. Digital literacy is the ability to use digital media that aims to find, evaluate, utilize, share and create information and make good use of it through technology and the internet (H. Anggraeni et al., 2019; Fortuna et al., 2020; Masitoh, 2018). It is not by the situation in the field where the implementation of digital literacy has not run because there are several obstacles such as only being centred on WhatsApp groups and skills in utilizing digital literacy are still minimal, especially in the application during the learning process where there is a lack of feedback between teachers and students.

It is in line with previous research, which stated that the biggest challenge in implementing digital literacy in schools is based on internal schools, including the ability of the teachers (H. Anggraeni et al., 2019; Hanik, 2020; Lestari et al., 2020). It is less than optimal in terms of the intensity of the application and use of digital literacy in learning activities. Some contributing factors include students having difficulty asking the teacher and the lack of feedback during the online learning process. As a result, students find it difficult to interact online, unlike a classroom where students can interact easily. The teacher also said that digital literacy is still lacking because it only uses WhatApp groups. It is because many students still do not understand using e-mail. In terms of the level of understanding of principals, teachers, education staff, and students in using digital media and the internet, the results show that respondents have an understanding of using digital media and the internet, only that their use and utilization is not optimal, especially in the learning process. It is evident when the learning process only uses WhatsApp group media to implement digital literacy. Meanwhile, the understanding of the internet is also good because in using the internet, school principals, teachers, education staff, and students access through electronic media such as cellphones, laptops and computers. Electronic media also has an essential role in implementing the implementation of digital literacy. Electronic media supports the application of digital literacy (Anggrasari, 2020; A. E. Putri, 2020; Sari, 2019). In terms of the number and variety of digital-based reading materials and teaching aids, they are not yet available in schools. Schools can hold a program of reading materials and digital-based teaching aids so that students get used to and have more understanding and abilities because there are already supports for the implementation of digital literacy (Kurnia \& Astuti, 2017a; Rastati, 2018).

Teachers can combine it with other media such as google meet, zoom meeting and google classroom and also with the help of social media such as Facebook, youtube and Instagram (Bernadetha, 2020; Kholid, 2020). However, it is also necessary to understand students' understanding of using digital literacy by utilizing digital media. So, there needs to be an equality of understanding between teachers and students so that the learning process runs smoothly and creates feedback between teachers and students. With this habit, students can also access various quality learning resources at school and outside of school independently (Irhandayaningsih, 2020; Nahdi \& Jatisunda, 2020). Success in the implementation of digital literacy is not obtained spontaneously, and several actions are needed to support the implementation of digital literacy so that it runs smoothly, such as holding training, manuals for using digital literacy and providing reading materials and digital-based teaching aids in schools.

\section{CONCLUSION}

The implementation of digital literacy in elementary schools is still not optimal in applying and utilising the learning process. It is due to several factors, such as the lack of digital literacy themed training so that knowledge about digital literacy is still minimal, the lack of direction and teaching about procedures for using digital literacy, the lack of reciprocity during the learning process between teachers and students. Thus, it is necessary to understand digital literacy further so that the type of digital literacy media used is 
not focused on WhatsApp groups only. Meanwhile, in the use of technology, principals, teachers, students, and education staff are good because every activity uses electronic media in cellphones, laptops and computers.

\section{REFERENCES}

Agustini, D., Lian, B., \& Sari, A. P. (2020). School'S Strategy for Teacher'S Professionalism Through Digital Literacy in the Industrial Revolution 4.0. International Journal of Educational Review, 2(2), 160173. https://doi.org/10.33369/ijer.v2i2.10967.

Aiman, U., Amelia, R., \& Ahmad, R. (2020). Model Pembelajaran Berbasis Masalah (PBL) Terhadap Literasi Sains Siswa Kelas V Sekolah Dasar. Jurnal Pendidikan Dasar Flobamorata, 1(1), 1-5. https: //doi.org/10.51494/jpdf.v1i1.195.

Akhyar, Y., Syarif, M. I., Fitri, A., Simbolon, P., S, A. P., Tryana, N., \& Abidin, Z. (2021). Contribution of Digital Literacy to Students ' Science Learning Outcomes in Online Learning. International Journal of Elementary Education, 5(2), 284-290. https://doi.org/10.23887/ijee.v5i2.34423.

Anggraeni, H., Fauziyah, Y., \& Fahyuni, E. F. (2019). Penguatan Blended Learning Berbasis Literasi Digital Dalam Menghadapi Era Revolusi Industri 4.0. Al-Idarah : Jurnal Kependidikan Islam, 9(2), 190-203. https://doi.org/10.24042/alidarah.v9i2.5168.

Anggraeni, S. W., Alpian, Y., \& Kodariah, S. (2021). Primary School Students' Learning Anxiety during the COVID-19 Pandemic. International Journal of Elementary Education, 5(1), 1-10. https://doi.org/10.23887/ijee.v5i1.33036.

Anggrasari, L. A. (2020). Penerapan e-learning untuk meningkatkan kemampuan literasi digital di era new normal. Premiere Educandum: Jurnal Pendidikan Dasar Dan Pembelajaran, 10(2), 248. https://doi.org/10.25273/pe.v10i2.7493.

Arizona, K., Abidin, Z., \& Rumansyah, R. (2020). Pembelajaran Online Berbasis Proyek Salah Satu Solusi Kegiatan Belajar Mengajar Di Tengah Pandemi Covid-19. Jurnal Ilmiah Profesi Pendidikan, 5(1). https://doi.org/10.29303/jipp.v5i1.111.

Asari, A., Kurniawan, T., Ansor, S., Bagus, A., \& Rahma, N. (2019). Kompetensi Literasi Digital Bagi Guru Dan Pelajar Di Lingkungan Sekolah Kabupaten Malang. BIBLIOTIKA: Jurnal Kajian Perpustakaan Dan Informasi, 3, 98-104. http://journal2.um.ac.id/index.php/bibliotika/article/view/11592.

Awe, E. Y., \& Benge, K. (2017). Hubungan Antara Minat Dan Motivasi Belajar Dengan Hasil Belajar Ipa Pada Siswa Sd. Journal of Education Technology, 1(4), 231. https://doi.org/10.23887/jet.v1i4.12859.

Balan, S., Katenga, J. E., \& Simon, A. (2019). "Reading Habits and their Influence on Academic Achievement among Students at Asia Pacific International University, Thailand.” Abstract Proceedings International Scholars Conference, 7(1), 1469-1495. https://doi.org/10.35974/isc.v7i1.928.

Banyu Biru, R. C., Saepudin, A., \& Sardin. (2020). Analisis Literasi Digital Terhadap Pembelajaran Mandiri Di Masa Pandemi Covid-19. IJACE Indonesian Journal Of Adult and Community Education, 2(2), 61-69.

Basar, A. M. (2021). Problematika Pembelajaran Jarak Jauh Pada Masa Pandemi Covid-19. Edunesia : Jurnal Ilmiah Pendidikan, 2(1), 208-218. https://doi.org/10.51276/edu.v2i1.112.

Benbow, R. J., Lee, C., \& Hora, M. T. (2021). Exploring college faculty development in 21st-century skill instruction: an analysis of teaching-focused personal networks. Journal of Further and Higher Education, 45(6), 818-835. https://doi.org/10.1080/0309877X.2020.1826032.

Bernadetha, N. (2020). The effectiveness of distance learning using social media during the pandemic period of covid-19: A case in universitas kristen indonesia. International Journal of Advanced Science and Technology, 29(7), 1764-1772.

Chai, C. S., \& Kong, S.-C. (2017). Professional learning for 21st century education. Journal of Computers in Education, 4(1), 1-4. https://doi.org/10.1007/s40692-016-0069-y.

Desi, Y. P. (2020). Gerakan Literasi Digital Berbasis Sekolah: Implementasi dan Strategi. Jurnal Ilmu Komunikasi, 17(1), 51. https://doi.org/10.31315/jik.v17i1.3510.

Fatimah. (2020). Digital Literacy and Its Relationship to Early Childhood Behavior in PAUD. Kanal: Jurnal Ilmu Komunikasi, 9(1), 28-32. https://doi.org/10.21070/kanal.v9i1.663.

Febriliani, L. (2018). Hubungan Minat Belajar Dan Fasilitas Belajar Terhadap Hasil Belajar Matematika Kelas V. Joyful Learning Journal, 7(2), 10-18. https://doi.org/10.15294/jlj.v7i2.24049.

Fortuna, A. P., Rida, A. M., Maharani, L. S. P., Ardiansyah, R., \& Sari, A. A. (2020). A needs analysis of digital connecting book in education in the pandemic era. ACM International Conference Proceeding Series. https://doi.org/10.1145/3452144.3452154.

Garbacz, S. A., Sheridan, S. M., Koziol, N. A., Kwon, K., \& Holmes, S. R. (2015). Congruence in parent-teacher communication: Implications for the efficacy of CBC for students with behavioral concerns. School Psychology Review, 44(2), 150-168. https://doi.org/10.17105/spr-14-0035.1. 
Ghory, S., \& Ghafory, H. (2021). The impact of modern technology in the teaching and learning process. International Journal of Innovative Research and Scientific Studies, 4(3), 168-173. https://doi.org/10.53894/ijirss.v4i3.73.

Ginanjar, A., Putri, N. A., Nisa, A. S., Hermanto, F., \& Mewangi, A. B. (2019). Implementasi Literasi Digital Dalam Proses Pembelajaran Ips Di Smp Al-Azhar 29 Semarang. Harmony, 4(2), 99-105.

Gürsoy, G. (2021). Digital storytelling: Developing 21st century skills in science education. European Journal of Educational Research, 10(1), 97-113. https://doi.org/10.12973/EU-JER.10.1.97.

Hanik, E. U. (2020). Self directed learning berbasis literasi digital pada masa pandemi covid-19 di Madrasah $\begin{array}{llllll}\text { Ibtidaiyah. ELEMENTARY: Islamic Teacher Journal, } & \text { 8(1), }\end{array}$ https://doi.org/10.21043/elementary.v8i1.7417.

Huseyin, Demirezen, M., \& Pourfeiz, J. (2015). Digital Device Ownership, Computer Literacy, And Attitudes Toward Foreign And Computer-Assisted Language Learning. Procedia - Social and Behavioral Sciences, 186. https://doi.org/10.1016/j.sbspro.2015.04.028.

Hutauruk, A., \& Sidabutar, R. (2020). Kendala pembelajaran daring selama masa pandemi di kalangan mahasiswa pendidikan matematika: Kajian kualiatatif deskriptif. Journal of Mathematics Education and Applied, 02(01), 45-51. https://doi.org/10.36655/sepren.v2i1.364.

Irhandayaningsih, A. (2020). Pengukuran literasi digital pada peserta pembelajaran daring di masa pandemi covid-19. Anuva, 4(2), 231-240.

Kholid. (2020). Pentingnya Literasi Digital bagi Guru Pada Lembaga Pendidikan Tingkat Dasar dan Implikasinya Terhadap Penylenggaraan Kegiatan Belajar Mengajar. Jurnal Horizon Pendagogia, 2227. https://jurnal.untirta.ac.id/index.php/jhp/article/view/10422/6784.

Khosiyah, M., \& Gunawan. (2019). Pengembangan Media Belajar Berbasis Android Pada Materi Tata Surya Untuk Siswa Sekolah Dasar. Elementa: Jurnal Prodi Pgsd Stkip Pgri Banjarmasin, 1(1), 1-8.

Koyuncu, İ., \& Firat, T. (2020). Investigating reading literacy in PISA 2018 assessment. International Electronic Journal of Elementary Education, 13(2), 263-275. https://doi.org/10.26822/iejee.2021.189.

Kurnia, N., \& Astuti, S. I. (2017a). Peta Gerakan Literasi Digital di Indonesia: Studi Tentang Pelaku, Ragam Gerakan, Kelompok Sasaran dan Mitra. Informasi Kajian Ilmu Komunikasi, 47(2), 149-166. https://doi.org/10.21831/informasi.v47i2.16079.

Kurnia, N., \& Astuti, S. I. (2017b). Peta Gerakan Literasi Digital Di Indonesia: Studi Tentang Pelaku, Ragam Kegiatan, Kelompok Sasaran Dan Mitra Yang Dilakukan Oleh Japelidi. Informasi, 47(2), 149. https://doi.org/10.21831/informasi.v47i2.16079.

Kurnianingsih, I., Rosini, R., \& Ismayati, N. (2017). Upaya Peningkatan Kemampuan Literasi Digital Bagi Tenaga Perpustakaan Sekolah dan Guru di Wilayah Jakarta Pusat Melalui Pelatihan Literasi Informasi. Jurnal Pengabdian Kepada Masyarakat (Indonesian Journal of Community Engagement), 3(1), 61. https://doi.org/10.22146/jpkm.25370.

Lacka, E., Wong, T. C., \& Haddoud, M. Y. (2021). Can digital technologies improve students' efficiency? Exploring the role of Virtual Learning Environment and Social Media use in Higher Education. Computers \& Education, 163. https://doi.org/10.1016/j.compedu.2020.104099.

Lase, D., Zega, T. G. C., \& Daeli, D. O. (2021). Parents' Perceptions of Distance Learning during CoVID-19 Pandemic in Rural Indonesia. SSRN Electronic Journal, 13(2), 101-111. https://doi.org/10.2139/ssrn.3890610.

Lestari, H., Siskandar, R., \& Rahmawati, I. (2020). Digital Literacy Skills of Teachers in Elementary School in The Revolution 4.0. Journal International Conference on Elementary Education, 2(1), 302-311.

Marsh, J. (2016). The Digital Literacy Skills and Competences of Children of Pre-School Age. Media Education, 7(2), 197-214. https://doi.org/10.14605/MED721603.

Masitoh, S. (2018). Blended Learning Berwawasan Literasi Digital Suatu Upaya Meningkatkan Kualitas Pembelajaran dan Membangun Generasi Emas 2045. Proceedings of the ICECRS, 1(3), 13-34. https://doi.org/10.21070/picecrs.v1i3.1377.

Maulana, I. T., \& Padang, S. I. (2021). E-Learning effective during the Covid-19 era. Illköğretim Online, 20(2), 179-188. https://doi.org/10.17051/ilkonline.2021.02.20.

Monitorir, R. (2020). Dampak Pandemi Covid-19 Terhadap Kepuasan Pembelajaran Jarak Jauh. Jurnal Inovasi Teknologi Pendidikan, 7(1). https://doi.org/10.21831/jitp.v7i1.32771.

Nahdi, D. S., \& Jatisunda, M. G. (2020). Analisis Literasi Digital Calon Guru Sd Dalam Pembelajaran Berbasis Virtual Classroom Di Masa Pandemi Covid-19. Jurnal Cakrawala Pendas, 6(2), 116-123. https://doi.org/10.31949/jcp.v6i2.2133.

Nur Ika Fatmawati. (2019). Literasi Digital, Mendidik Anak Di Era Digital Bagi Orang Tua Milenial. Madani Jurnal Politik Dan Sosial Kemasyarakatan, 11(2), 119-138. https://doi.org/10.52166/madani.v11i2.1602. 
Pohan, S. S., \& Suparman. (2020). Perspektif Literasi Digital Bagi Guru Sekolah Dasar. Jurnal Ilmu-Ilmu Sejarah, Sosial, Budaya Dan Kependidikan, 7(1), 164-178.

Pramudyani, A. V. R. (2020). The Effect of Parenting Styles for Children's Behaviour on Using Gadget at Revolution Industry. Jurnal Obsesi: Jurnal Pendidikan Anak Usia Dini, 5(1), 51. https://doi.org/10.31004/obsesi.v5i1.520.

Purnama, S., Ulfah, M., Machali, I., Wibowo, A., \& Narmaditya, B. S. (2021). Does digital literacy influence students' online risk? Evidence from Covid-19. Heliyon, 7(6). https://doi.org/10.1016/j.heliyon.2021.e07406.

Putri, A. E. (2020). Analisis Kebutuhan Bahan Ajar Berbasis Literasi Digital Nilai-Nilai Kearifan Lokal pada Tradisi Saprahan di Pontianak. Yupa: Historical Studies Journal, 3(1), 1-7. https://doi.org/10.30872/yupa.v3i1.132.

Putri, I. I. M., Rmiyanti, R., \& Ningsih, E. R. (2020). Realisasi Gerakan Literasi Digital Sebagai Implementasi Gerakan Literasi Nasional Di Sekolah Muhammadiyah Pangkalan Bun. Buletin Literasi Budaya Sekolah, 2(2), 87-99. https://doi.org/10.23917/blbs.v2i2.12836.

Radyuli, P., \& Rahmat, V. (2017). Korelasi Disiplin Belajar dan Kreativitas Belajar Terhadap Minat Belajar Teknologi Informasi dan Komunikasi ( TIK ). Jurnal Pendidikan Dan Teknologi Informasi, 4(2), 262271. https://doi.org/10.23887/jipp.v3i3.21834.

Rastati, R. (2018). Media Literasi Bagi Digital Natives: Persektif Generasi Z Di Jakarta. Kwangsan: Jurnal Teknologi PendidikanJurnal Teknologi Pendidikan, 6(1). https://doi.org/10.31800/jtp.kw.v6n1.p60--73.

Ristanto, R. H., Rusdi, R., Mahardika, R. D., Darmawan, E., \& Ismirawati, N. (2020). Digital Flipbook Imunopedia (DFI): A Development in Immune System e-Learning Media. International Journal of Interactive Mobile Technologies (IJIM), $140-162$. https: //doi.org/10.3991/ijim.v14i19.16795.

Rizaldi, D. R., Nurhayati, E., \& Fatimah, Z. (2020). The Correlation of Digital Literation and STEM Integration to Improve Indonesian Students' Skills in 21st Century. International Journal of Asian Education, 1(2), 73-80. https://doi.org/10.46966/ijae.v1i2.36.

Rochadiani, T. H., Santoso, H., \& Dazki, E. (2020). Peningkatan Literasi Digital Pada Masa Pandemi Covid-19. Jurnal Pengabdian Masyarakat Universitas Pradita 1(1). Pengabdian Masyarakat Universitas Pradita, 1, Nomor 1, 1-11.

Safitri, I., Marsidin, S., \& Subandi, A. (2020). Analisis Kebijakan terkait Kebijakan Literasi Digital di Sekolah Dasar. Edukatif: Jurnal Ilmu Pendidikan, 2(2), 176-180. https://doi.org/10.31004/edukatif.v2i2.123.

Sahidillah, M. W., \& Miftahurrisqi, P. (2019). Whatsapp sebagai Media Literasi Digital Siswa. Jurnal VARIDIKA, 1(1), 52-57. https://doi.org/10.23917/varidika.v1i1.8904.

Salehudin, M. (2020). Literasi Digital Media Sosial Youtube Anak Usia Dini. Jurnal Ilmiah Potensia, 5(2), 106115. https://doi.org/10.33369/jip.5.2.\%25p.

Santoso, A., \& Lestari, S. (2019). The Roles of Technology Literacy and Technology Integration to Improve Students' Teaching Competencies. KnE Social Sciences, 3(11), 243. https://doi.org/10.18502/kss.v3i11.4010.

Sari, S. (2019). Literasi Media Pada Generasi Milenial Di Era Digital. Jurnal Komunikasi Dan Administrasi Publik, 6(2). https://doi.org/10.37676/professional.v6i2.943.

Simanjuntak, S. Y., Kismartini, Dwimawanti, I. H., \& Hidayatullah, M. A. (2020). Respons Guru Terhadap Kebijakan Pembelajaran Jarak Jauh Selama Pandemi Covid-19. Jurnal Ilmiah Pendidikan Citra Bakti, 7(2), 125-136. https://doi.org/10.38048/jipcb.v7i2.108.

Sujendra Diputra, K., Ketut Desia Tristiantari, N., Nyoman Laba Jayanta, I., Pendidikan Guru Sekolah Dasar, P., \& Pendidikan Ganesha, U. (2020). Gerakan Literasi Digital Bagi Guru-Guru Sekolah Dasar. JCES (Journal of Character Education Society), 3(1), 118-128.

Suyono, Harsiati, \& Wulandari. (2017). Implementasi Gerakan Literasi Sekolah pada Pembelajaran Tematik di Sekolah Dasar Sekolah Dasar: Kajian Teori dan Praktik Pendidikan. Jurnal Sekolah Dasar Kajian Teori Dan Praktik Pendidikan, 26(2), 116-123. https://doi.org/10.17977/um009v26i22017p116.

Teräs, M., Suoranta, J., Teräs, H., \& Curcher, M. (2020). Post-Covid-19 Education and Education Technology 'Solutionism': a Seller's Market. Postdigital Science and Education, 2(3), 863-878. https: //doi.org/10.1007/s42438-020-00164-X.

Tse, W. S., Choi, L. Y. A., \& Tang, W. S. (2019). Effects of video-based flipped class instruction on subject reading motivation. British Journal of Educational Technology, 50(1), 385-398. https://doi.org/10.1111/bjet.12569.

Windhiyana, E. (2020). Dampak Covid-19 Terhadap Kegiatan Pembelajaran Online Di Perguruan Tinggi Kristen Di Indonesia. Perspektif Ilmu Pendidikan, 34(1), 1-8. https://doi.org/10.21009/pip.341.1. 